\title{
Correction to: Synergic Effect of catalyst/binder in passivation side-products of Li-Oxygen cells
}

\author{
Paulina Márquez $^{1} \cdot$ Julia Amici $^{2}$ (D) María Jesús Aguirre ${ }^{1} \cdot$ Francisco Herrera $^{1} \cdot$ Carlotta Francia $^{2} \cdot$ Silvia Bodoardo $^{2}$
}

Published online: 13 December 2019

(C) Springer-Verlag GmbH Germany, part of Springer Nature 2019

\section{Correction to: J Solid State Electrochem}

https://doi.org/10.1007/s10008-019-04417-z

The Authors regret that, in the published version, Figure 2 was substituted by Figure 1.

The correct Figure 2 is reported below:

The online version of the original article can be found at https://doi.org/ 10.1007/s10008-019-04417-z

\footnotetext{
Julia Amici

julia.amici@polito.it

1 Departamento de Química de los Materiales, Facultad de Química y

Biología, Universidad de Santiago de Chile (USACH), Av. B.

O’Higgins 3363, Estación Central, Santiago, Chile

2 Department of Applied Science and Technology (DISAT),

Politecnico di Torino, C.so Duca degli Abruzzi 24,

10129 Torino, Italy
} 

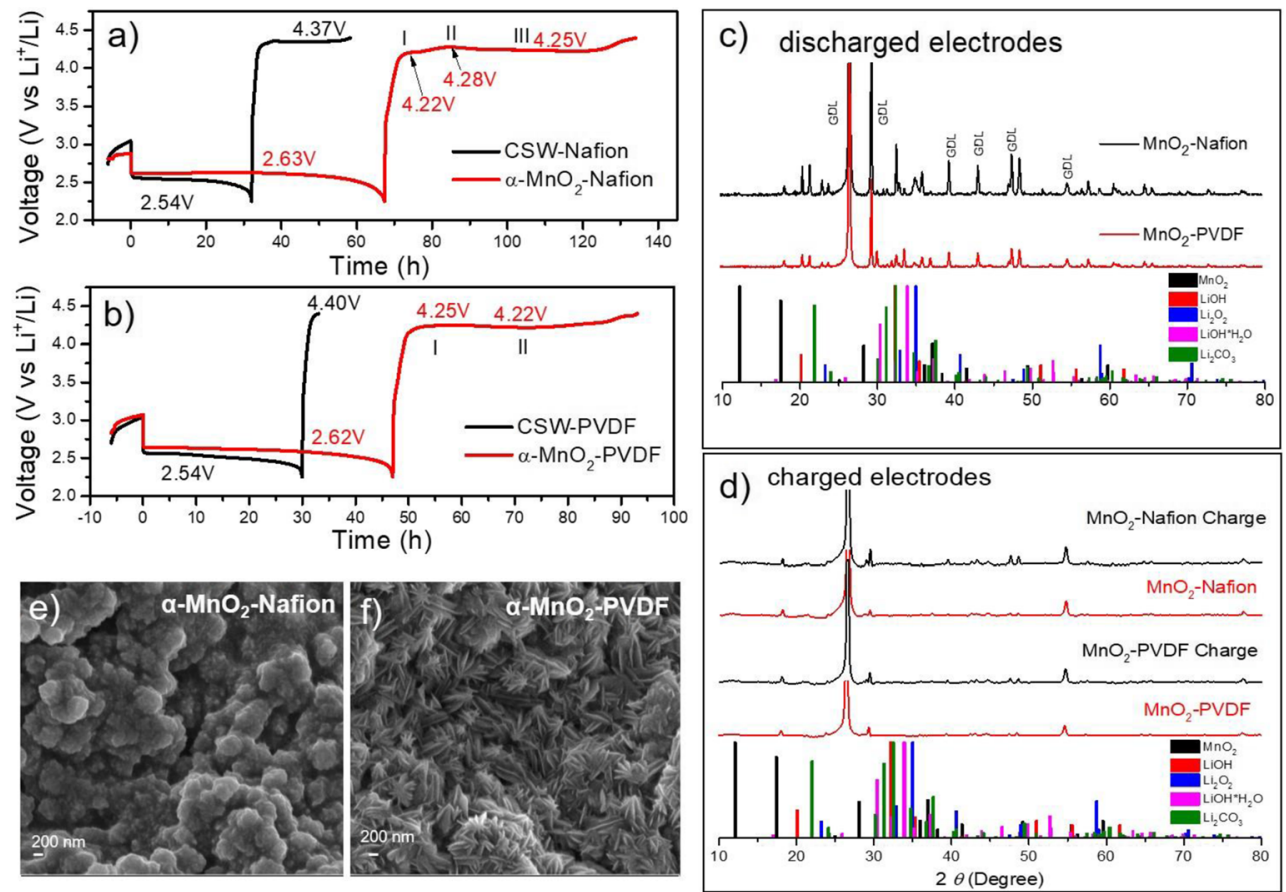

Fig. 2 Discharge/charge profiles of the air electrodes (under $0.1 \mathrm{~mA} \mathrm{~cm}$ 2 current densities and continuously fed by a $3 \mathrm{ml}$ min-1 O2 flow) with CSW and Nafion against $\alpha-\mathrm{MnO} 2$ and Nafion (a), CSW and PVDF against $\alpha-\mathrm{MnO} 2$ and PVDF (b), XRD patterns of MnO2 Nafion and

MnO2 PVDF discharged cathodes $(0.1 \mathrm{~mA} \mathrm{~cm}-2)$ (c) and of same electrodes after recharge $(0.1 \mathrm{~mA} \mathrm{~cm}-2)$, compared to pristine electrodes $(\mathbf{d})$, FESEM images of discharged $\alpha-\mathrm{MnO} 2$ Nafion cathodes surface (e) and $\alpha-\mathrm{MnO} 2 \mathrm{PVDF}$ cathodes surface (f).

Moreover, if possible, the Authors would like the following acknowledgement added:

The Authors wish to thank Dr. Freddy Celis for Raman analysis.

This work was supported by Conicyt-PCHA; Doctorado Nacional, 2014, Dicyt_USACH 051831EM_DAS, Fondecyt

1131019 and 1160324 projects (Prof María Jesús Aguirre), as well as ENEA PAR 2017 (Prof. Silvia Bodoardo).

The authors apologize for any caused inconvenience. 